\title{
Does single locked plating provide a standard treatment Modality for bicondylar tibial plateau fractures? A prospective study
}

Ahmed Hasan Elbana Youssef*, Ahmed Nagi, Wessam Gamal Abu Senna, Sherif Abdelatif Othman and Hassan Elgamal

*Correspondence: dr_medo08@icloud.com

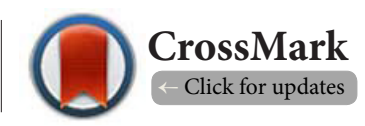

Orthopedic Surgery Department, Al-Razi Orthopaedic Hospital, Kuwait.

\begin{abstract}
Background: Bicondylar tibial plateau fractures present a therapeutic challenge to the orthopaedic trauma surgeon, both in terms of the osseous injury as well as the concomitant soft-tissue insult. Double Plating with single incision or dual incisions provide more insult to the compromised soft tissue. However, single locking plate combines the technical advantages of an angular stable plate with those of the modern biological plating technique.

Methods: The Study was held at Razi Orthopedic hospital in Kuwait. Between May 2012 and November 2013, 20 patients with a mean age of 37.65 years (Range from 24- 57 years) with bicondylar tibial plateau fractures with or without metaphyseal extension. Patients were diagnosed clinically, checked with standard X-rays, CT was done for all cases. Patients were treated by single lateral anatomically contoured locked plate through LISS or Polyaxial locking plate systems with or without additional screws from medial side. Radiological evaluation and functional assessment was done according to the Rasmussen Knee score. Patients were followed-up for an average of 12 months.

Results: Union was achieved in all patients with a mean knee range of motion of $1.5^{\circ}-130^{\circ}$ (range: $0^{\circ}-10^{\circ}$ for extension lag, range: $100^{\circ}-135^{\circ}$ for flexion). The mean Functional Rasmussen Knee score at 6 month follow up (25.32 $1.53 \mathrm{SD}$ ) ranged from (23.0-28.0). The mean Functional Rasmussen Knee score at last follow-up was (28.33 $\pm 1.57 \mathrm{SD})$ ranged between (25.0-30.0) with significant $\mathrm{P}$ value ( $\mathrm{P}$ value $<0.001)$. The mean Anatomical Rasmussen Knee score at 6 month follow up (16.11 $\pm 1.56 \mathrm{SD}$ ) ranged from (14.0-18.0). The mean Anatomical Rasmussen Knee score at last follow-up was (16.67 $1.37 \mathrm{SD})$ ranged from (14.0-18.0) with insignificant $\mathrm{P}$ value ( $\mathrm{P}$ value 0.096 ). Of the 20 patients, one patient had wound related problems, one patient had preoperative compartment syndrome, one patient suffered from hardware irritation and one patient had fixation failure upon which revision with double plating done for him.

Conclusions: Surgical treatment of bicondylar tibial plateau fractures with the single lateral locked plate that was evaluated in our study can lead to a good functional and anatomical outcome and considered an effective system for providing fracture stabilization provided that the correct surgical technique is used. Awareness of potential hardware complications is essential.

Level of Evidence: Level IV, Prospective Therapeutic Study

Keywords: Bicondylar Tibial Plateau Fractures, Locked Plates, Schatzker Classification, Rasmussen Knee score

Tibial plateau fractures constitute $1 \%$ of all fractures and $8 \%$ of fractures in the elderly [1]. Bicondylar tibial plateau fractures are

complex injuries and treatment these fractures is challenging. Ideal method is still controversial with risk of unsatisfactory results ifnottreated properly [2].
\end{abstract}

\section{Introduction}


Several strategies have been advocated for management of bicondylar tibial plateau fractures. Treatment options include external fixation, circular or hybrid frames, or internal fixation. When internal fixation is chosen, either dual plating (medial and lateral plates) or lateral locked plating have been advocated. There is no consensus on the relative merits of single plate versus dual plate constructs or nonlocking versus locking screws [3].

Several Authors introduced the concept of "indirectreduction" of fractures, the goal of which is to obtain reduction without damaging the surrounding soft tissues, or without operating directly in the fracture site. Based on these concepts, the LISS (Less Invasive StabilisationSystem) and ZPLP (Zimmer Periarticular Locking Platesystem) have been studied and developed. These minimallyinvasive systems have the function of an "internalfixator" [4-6].

To assist in resolving this controversy, we hypothesised that bicondylar tibial plateau fractures (Schatzker V, VI) would be effectively stabilised using a single lateral anatomically contoured locked plate. Our main evaluation criterion was radiological stability and functional outcome from the immediate postoperative period till healing.

\section{Methods}

We conducted prospective study from May 2012 to November 2013. Twenty patients with a mean age of 37.65 years (Range from 24-57 years) having bicondylar tibial plateau fractures (Schatzker V, VI) were evaluated after obtaining informed consent to participate in our study. Table 1 reports the main epidemiological data.

Inclusion criteria were bicondylar tibial plateau fractures with or without metaphyseal extension. Fractures were classified by Schatzker classification. Exclusion criteria were patients with other types of fracture tibial plateau, patients have contraindications for surgery, patients with open fractures, patients with active infections and lack of patient compliance.

\section{Description of surgery}

I. Surgery was done within 24-48 hours from injury for all patients under epidural anaesthesia. Patient were placed supine with the knee semiflexed on radiolucent traction table to assist in reduction and maintain alignment by ligamentotaxis.

II. After proper draping, a short oblique anterolateral incision was made just proximal to the origin of tibialis anterior muscle distally and up to Gerdy's tubercle just distal to the joint then the fascia is released. Exposure of the lateral surface of the proximal tibia is performed with a periosteal elevator. The knee joint can be exposed, if needed, via a minimal dissection and submeniscal arthrotomy where needed. If the meniscus is incarcerated in the fracture, it was extracted and stitched if possible.

III. In displaced intraarticular fractures, our priority was reducing the articular surface before plate application. First, Medial plateau fracture should be reduced and fixed. Once temporarily reduced, cancellous bone screws were utilized for compression independently outside of the plate as needed or within the metaphyseal head of the locked plate.

IV. Then, reduction of articular portion of lateral plateau by the same manner after elevation of depressed articular surface ifpresent. If there was large intercondylar imenence fragment, it was reduced and fixed. Calcium phosphate ceramic bone graft was used in 2 cases for filling defects.

V. According to availability of number of plate holes needed for fixation, we used Less Invasive Stabilization System (LISS, Synthes USA, Paoli, PA, USA) for fixation of 14 tibial plateau fractures. Polyaxial Locked Plate System (Depuy, Warsaw, Indiana) used for remaining 6 fractures. No intention to treat by specific implant according to geometry of fracture.

VI. Finally, we confirmed fixation under fluoroscopic image guidance in both AP and lateral views. Then reexamined the limb for alignment before wound closure. A suction drain was used in all patients. Finally closure of the subcutaneous and skin layers was done. Post operative Plain X ray films (AP\& Lateral views) were done for documentation and assessment of progress of bone healing later on.

\section{Aftercare}

1- Intravenous antibiotic in the form of third-generation cephalosporins (Ceftriaxone) as a prophylaxis was given for all patients starting from the day of surgery and continued till drain removal after 48 hours. An anticoagulation therapy and antiembolic stockings were used up to the start of ambulation from bed.

2- Continuos Passive motion (C.P.M) machine that started on the first postoperative day in conformity with the degree of stability of the fixation from (0-90) degree and continued till reaching the acceptable range. Knee brace was used between sessions of physiotherapy. Active-assisted isometric exercises of the knee were started at that time and were continued up to 6 weeks. Non Weight Bearing(NBW) was started after removal of drain using walking frame followed by crutches.

3- All patients were discharged from the hospital when wound condition was OK ( i.e no signs of infection), active range of motion at least $\left(0-90^{\circ}\right)$ and patients were walking steady N.W.B. on the affected limb with crutches.

\section{Description of followup routine}

1-First visit was within 14 days from surgery for check up of the wound and removal of stitches if wound looked healed. Range of Motion (R.O.M.) was checked and recorded. Second visit was at 6-8 weeks, third visit was at 4-6 months with the start of F.W.B., fourth visit was at 9 months and fifth visit was at 12 months unless complications occurred (Figure 1).

2-Each visit had clinical evaluation of the wound, measuring R.O.M. and plain (AP\&lateral) X-rays.

3-Deep infection was defined as infection of the wound recurring debridement. Secondary loss of reduction was defined as an increase of $2 \mathrm{~mm}$ of intra-articular step-off and secondary 
Table 1. Main epidemiological data in the 20 patients.

\begin{tabular}{lllllll}
\hline Patient\# & $\begin{array}{l}\text { Age } \\
\text { (Years) }\end{array}$ & Sex & Occupation & $\begin{array}{l}\text { Mode of } \\
\text { Trauma }\end{array}$ & $\begin{array}{l}\text { Schatzker } \\
\text { Classification }\end{array}$ & Complication \\
\hline $\mathbf{1}$ & 29 & Male & Mannual Worker & M.V.A. & VI & NO \\
$\mathbf{2}$ & 48 & Male & Manual Worker & F.F.H. & VI & NO \\
$\mathbf{3}$ & 49 & Male & Manual Worker & M.V.A. & V & NO \\
$\mathbf{4}$ & 39 & Male & Office Clerck & Domestic & v & NO \\
$\mathbf{5}$ & 27 & Female & Accountant & Domestic & vi & NO \\
$\mathbf{6}$ & 38 & Male & Engenier & M.V.A. & v & NO \\
$\mathbf{7}$ & 36 & Male & Manual Worker & M.V.A. & v & NO \\
$\mathbf{8}$ & 53 & Male & Retired & Domestic & VI & No \\
$\mathbf{9}$ & 24 & Male & Student & F.F.H. & vi & NO \\
$\mathbf{1 0}$ & 25 & Male & Manual Worker & M.V.A & vi & HARDWARE IRRITATION \\
$\mathbf{1 1}$ & 32 & Male & Office Clerck & M.V.A & v & NO \\
$\mathbf{1 2}$ & 34 & Male & Engenier & M.V.A. & v & NO \\
$\mathbf{1 3}$ & 38 & Male & Manual Worker & F.F.H. & VI & NO \\
$\mathbf{1 4}$ & 57 & Male & Retired & Domestic & v & NO \\
$\mathbf{1 5}$ & 28 & Female & None & Domestic & v & NO \\
$\mathbf{1 6}$ & 27 & Male & Manual Worker & F.F.H. & v & NO \\
$\mathbf{1 7}$ & 39 & Male & Police Officer & F.F.H. & vi & MALALIGNMENT \\
$\mathbf{1 8}$ & 51 & Male & Manual Worker & M.V.A. & vi & NO \\
$\mathbf{1 9}$ & 42 & Male & Manual Worker & M.V.A. & vi & Superficial Infection \\
$\mathbf{2 0}$ & 37 & Male & Manual Worker & M.V.A. & v & Preoperative Compartment S. \\
\hline & & & & & &
\end{tabular}

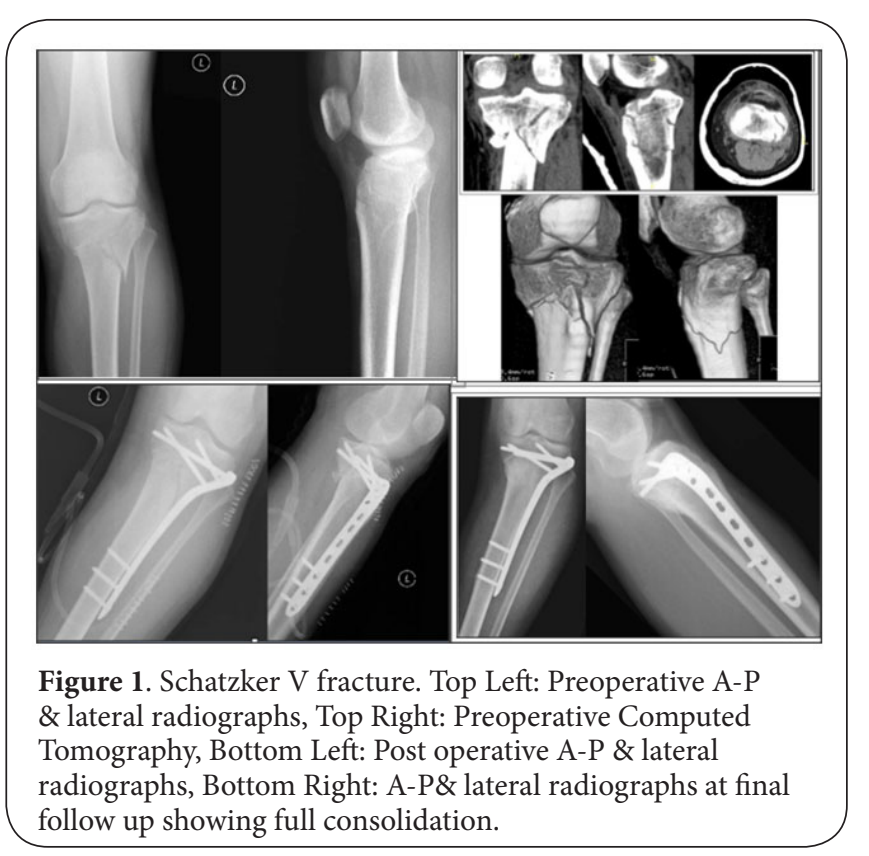

loss of alignment was defined as an increase of $3^{\circ}$ alignment when compared with the first post-operative radiograph.

4- Radiological union was defined as the presence of trabeculation crossing the fracture on radiographs of at least three cortices.

5-Clinical union was defined as the presence of painless full weight bearing. Nonunion was defined as no evidence of healing after 6 months.

6-Rasmussen knee scores (Functional and anatomical) [7] were used at serial intervals in the third visit with the start of F.W.B. and fifth visit.

7-The time of return to work from initial surgery was evaluated and compared between different age populations and type of fractures.

Variables, outcome measures, data sources, and bias Assessment of post operative $X$ rays as follows:

1- Assessment of articular incongruity: By measuring degree of step off (depth of depression) in AP radiographs. Malreduction was defined as intraarticular step-off of at least $3 \mathrm{~mm}$ measured on scaled radiographs.

2- Assesment of alignment of the proximal tibia: We defined alignment of the proximal tibia by measuring the the medial proximal tibial angle (MPTA) in the coronal plane and posterior proximal tibial angle (PPTA) in the sagittal plane (Figure 2). These angles were measured according to Freedman and Johnson [8].

MPTA is the medial angle between the tangential line and anatomical axis of the tibia in AP radiographs. (normal range: $82^{\circ}-92^{\circ}$ ). 


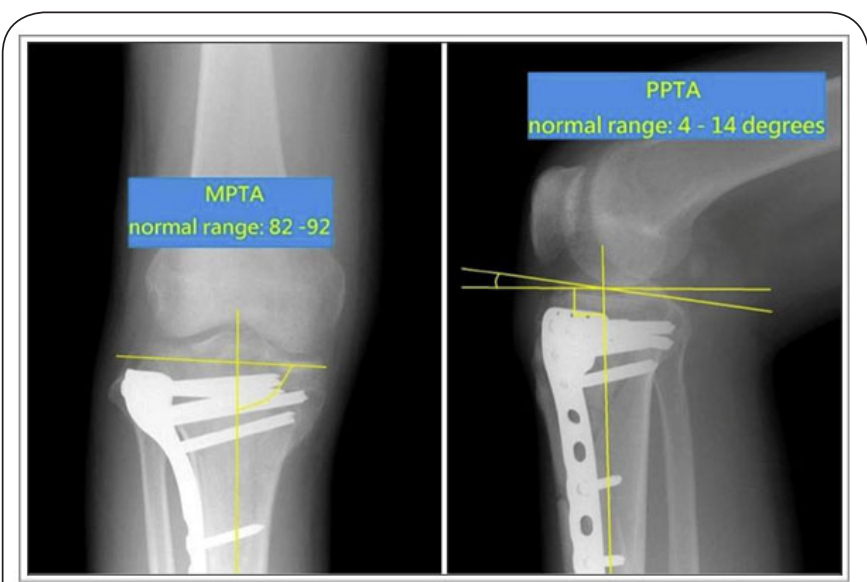

Figure 2. Radiographic measurement of MPTA and PPTA and normal reference range [8].

PPTA is the angle between the tangential line of medial plateau and the perpendicular line of the anterior tibial cortex on lateral radiographs. (normal range: $4^{\circ}-14^{\circ}$ ). The following angles were considered Malalignment in our study (MPTA $>92^{\circ}$ or MPTA $<82^{\circ}$, or PPTA $>14^{\circ}$, PPTA $<4^{\circ}$ ).

3- Each visit had clinical evaluation of the wound, measuring (R.O.M.) by goniometer and plain (AP\&lateral) X-rays. All clinical evaluation was done by the same person trying to reduce inter observer variability as possible. All radiographs were checked for magnification, penetration and exposure before measurements and observations were taken to eliminate magnification errors. All radiographs included in our study were taken by staff members from the same radiology department adhering to local guidelines and the set up for knee radiograph was standardized Figure 3.

4- Functional Grading of Rasmussen knee score with a total score (30 points) include the following :

A. Subjective Complaints (Pain and walking capacity)

B. Clinical signs (Extension, Total Range of motion and Stability). Acceptable Score (Excellent: 27 points, Good: 20 points). Unacceptable Score ( Fair: 10 points, Poor: 6 points).

5- Anatomical Grading of Rasmussen knee score with a total score (18 points) include the following :
a. Depression
b. Condylar Widening
c. Angulation (Varus/Valgus)

Acceptable Score (Excellent: 18 points, Good: 12 points). Unacceptable Score ( Fair: 6 points, Poor: 0 points).

\section{Statistical analysis, study size}

1-Paired t-test is the statistical hypothesis that was used in our study to compare Mean functional Rasmussen Knee Score during 6 and 12 months. p value was considered to be statistically significant at $\mathrm{p} \leq 0.05$.

2- ANOVA test was used for comparison between repeated measures of Joint depression, MPTA, PPTA and Condylar

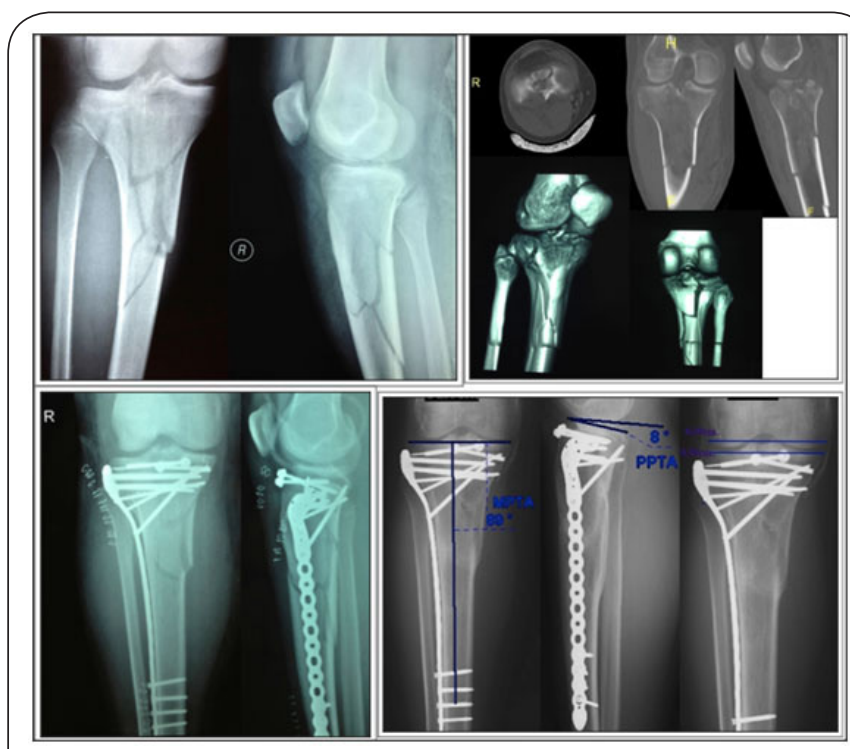

Figure 3. Schatzker VI fracture. Top Left: Preoperative A-P \& lateral radiographs, Top Right: Preoperative Computed Tomography, Bottom Left: Post operative A-P \& lateral radiographs, Bottom Right: A-P\& lateral radiographs at final follow up showing measurement of MPTA, PPTA and Condylar Wideninig.

Widening during postoperative period, 6 months and 12 months follow up. $p$ value was considered to be statistically significant at $\mathrm{p} \leq 0.05$.

3- All 20 patients were followed up for 12 months with no patient lost to follow up.

\section{Results}

1- The average predefined hospital stay was 5.2 days.

2-During follow up, it was observed that all patients had achieved union within an average duration of 4.8 months (range: 4-6 months).

3- Average time for full weight bearing was 16.4 weeks.

4- Mean knee range of motion of $1.5^{\circ}-130^{\circ}$ (range: $0^{\circ}-10^{\circ}$ for extension lag, range: $100^{\circ}-135^{\circ}$ for flexion).

5- Functional evaluation was done using Rasmussen Knee Scoring system at third visit ( 6 months) with the start of full weight bearing and fifth visit (12 months ) at final follow up Table 2.

6- Anatomical valuation was done using Rasmussen Knee Scoring system at third visit ( 6 months) with the start of full weight bearing and fifth visit (12 months) at final follow up Table 3.

7- ANOVA test was used for comparison between repeated measures of MPTA, PPTA (Table 4), Joint depression and Condylar Widening during postoperative period, 6 months and 12 months follow up. $p$ value was considered to be statistically insignificant in the above mentioned measurs.

8- Eleven patients returned to work after 4-5 months from surgery, 6 patients after 6 months, the other 3 patients were , 
Table 2. Distribution of the studied cases according to Mean functional Rasmussen Knee Score.

\begin{tabular}{lllll}
\hline & $\begin{array}{c}\text { 6 month } \\
(\mathbf{n}=\mathbf{1 9})\end{array}$ & $\begin{array}{c}\mathbf{1 2} \text { month } \\
(\mathbf{n}=\mathbf{1 8})\end{array}$ & $\mathbf{t}$ & $\mathbf{P}$ \\
\hline \multicolumn{4}{l}{ Mean functional rasmussen knee score } \\
\hline Min.-Max. & $23.0-28.0$ & $25.0-30.0$ & $15.858^{*}$ & $<0.001^{\star}$ \\
Mean \pm SD. & $25.32 \pm 1.53$ & $28.33 \pm 1.57$ & & \\
Median & 26.0 & 29.0 & & \\
\hline
\end{tabular}

${ }^{\mathrm{t}} \mathrm{p}$ : $\mathrm{p}$ value for Paired t-test for comparing between 6 and 12 months.

$*^{*}$ : Statistically significant at $\mathrm{p} \leq 0.05$.

Table 3. Distribution of the studied cases according to Mean anatomical Rasmussen Knee Score.

\begin{tabular}{lllll}
\hline & $\begin{array}{c}\text { 6 month } \\
(\mathbf{n}=\mathbf{1 9})\end{array}$ & $\begin{array}{c}\mathbf{1 2} \text { month } \\
(\mathbf{n}=\mathbf{1 8})\end{array}$ & $\mathbf{t}$ & $\mathbf{P}$ \\
\hline Mean anatomical rasmussen knee score & & \\
\hline Min.-Max. & $14.0-18.0$ & $14.0-18.0$ & $1.761^{*}$ & $0.096^{*}$ \\
Mean \pm SD. & $16.11 \pm 1.56$ & $16.67 \pm 1.37$ & & \\
Median & 16.0 & 16.0 & & \\
\hline
\end{tabular}

${ }^{\mathrm{t}} \mathrm{p}$ : $\mathrm{p}$ value for Paired t-test for comparing between 6 and 12 months

Table 4. Distribution of the studied cases according to MPTA, PPTA during postoperative, 6 months and 12 months.

\begin{tabular}{llll}
\hline MPTA & $\begin{array}{l}\text { Postoperative } \\
(\mathbf{n}=\mathbf{2 0})\end{array}$ & $\begin{array}{l}\mathbf{6} \text { months } \\
(\mathbf{n}=\mathbf{2 0})\end{array}$ & $\begin{array}{l}\mathbf{1} \text { months } \\
(\mathbf{n}=\mathbf{1 8})\end{array}$ \\
\hline Min. - Max. & $85.0-98.0$ & $83.0-91.0$ & $84.0-92.0$ \\
Mean \pm SD. & $89.45 \pm 2.95$ & $88.05 \pm 2.52$ & $88.06 \pm 1.89$ \\
Median & 90.0 & 88.50 & 88.0 \\
p & -- & 0.117 & 0.125 \\
\hline PPTA & $\begin{array}{l}\text { Postoperative } \\
(\mathbf{n}=\mathbf{2 0})\end{array}$ & $\begin{array}{l}\mathbf{6} \text { months } \\
(\mathbf{n}=\mathbf{2 0})\end{array}$ & $\begin{array}{l}\mathbf{1 2} \text { months } \\
(\mathbf{n}=\mathbf{1 8})\end{array}$ \\
\hline Min. - Max. & $6.0-14.0$ & $7.0-12.0$ & $7.0-11.0$ \\
Mean \pm SD. & $9.0 \pm 1.97$ & $9.0 \pm 1.12$ & $9.11 \pm 0.96$ \\
Median & 8.50 & 9.0 & 9.0 \\
p & -- & 0.707 & 0.386 \\
\hline
\end{tabular}

p: Stands for post hoc (LSD) p-value for ANOVA with repeated measures for comparison between postoperative and each other period

\section{2 retired and 1 not working.}

9-Regarding complications occurred in our study as follows; (16 cases- $80.0 \%$ ) without Complications , (4 cases- $20 \%$ )with Complications. The following Complications occured: Superficial infection (1 case- 5.0\%) resolved with antibiotics after Wound C.S. Preoperative compartment syndrome (1 case- 5.0\%) managed with Fasciotomy. Hardware irritation (1 case- 5.0\%) possibly due to long implant 13 holes. Fixation Failure (1 case5.0\%) managed by revision with double plating .

\section{Discussion}

Bicondylar tibial plateau fractures associated with high-energy trauma are frequently complex injuries that portend a poor prognosis. The status of the soft tissue envelope typically mirrors the amount of energy imparted to the bone. Traditionally, internal fixation of these injuries has been fraught with complications, including infections and wound breakdown. Biologic surgical treatment emphasises preservation of vascularity and soft-tissue integrity by minimizing further insult to the soft tissues [9].

Fixation of tibial plateau fractures has undergone dramatic change within the last decade with the advent of periarticular locking plates. One proposed clinical advantage of the locking plate is the ability to support the medial plateau and prevent varus collapse of bicondylar plateau fractures through a single laterally based implant [10]. Additionally, some of these plating systems also have guide arms facilitating percutaneous insertion and limited dissection, which may further reduce the soft-tissue insult of the surgery. The advantages of so-called submuscular plating are probably particularly important in high-energy injuries with significant soft-tissue swelling, and early results of these plates have provided encouraging results treating bicondylar fractures with a single laterally based locking plate [11].

One proposed clinical advantage of the locking plate is the ability to support the medial plateau and prevent varus collapse of bicondylar plateau fractures through a single, laterally based implant. This hypothesis was investigated by Gosling et al [12]. In a cadaveric study, concluding that the LISS plate and dual plating with traditional plates both provided similar resistance to permanent deformation of the construct under load.

Uniaxial locking systems have the advantage of not being able to manoeuvre locking screws around obstacles such as screws or other implants, or to target fracture fragments at different levels. This has forced research towards the development of polyaxial technology. The option of using a multi-trajectory locking screw instead of a fixed-angle one is achieved with various techniques which are widely used in clinical practice [13]. Our study suggests that single lateral locked plate can be an effective implant in providing fracture stabilization of bicondylar tibial plateau fractures.

(Table 5) Illustrates comparison between our study and other studies published since 2004 with the start of era of single lateral locked plating for bicondylar tibial plateau fractures.

By analysis of this table, single lateral locked plate can be an effective implant in providing fracture stabilization of bicondylar tibial plateau fractures. Understanding the potential hardware complications is important for anyone intending to use locked proximal tibial plate for the treatment of such fractures and it results in statistically significant functional outcome and good anatomical statistically insignificant outcome when utilized correctly.

Complications of our study are comparable to previous 
Table 5. Comparison between our study and other studies.

\begin{tabular}{|c|c|c|c|c|c|c|c|}
\hline & Our study & $\begin{array}{l}\text { Lee et al. [14] } \\
(2013)\end{array}$ & $\begin{array}{l}\text { Spagnolo et al. } \\
\text { [15](2012) }\end{array}$ & $\begin{array}{l}\text { Phisitkul et al. } \\
{[16](2007)}\end{array}$ & $\begin{array}{l}\text { Gosling et al. } \\
{[17](2005)}\end{array}$ & $\begin{array}{l}\text { Stannard et al. } \\
{[10](2004)}\end{array}$ & $\begin{array}{l}\text { Cole et al. [11] } \\
(2004)\end{array}$ \\
\hline No. of patients & 20 & 15 & 18 & 37 & 68 & 37 & 54 \\
\hline Type of study & Prospec-tive & Retrospective & Retrospec-tive & Retrosptive & Prospec-tive & Prospec-tive & Prospec-tive \\
\hline Mean age & 37.7 years & 43 years & 39 years & 45 years & 41.4 years & 42 years & 44 years \\
\hline Sex of patients & $\begin{array}{l}\text { Male } 90 \% \\
\text { Female } 10 \%\end{array}$ & $\begin{array}{l}\text { Male } 47 \% \\
\text { Female 53\% }\end{array}$ & $\begin{array}{l}\text { Male } 84 \% \\
\text { Female } 16 \%\end{array}$ & $\begin{array}{l}\text { Male } 60 \% \\
\text { Female } 40 \%\end{array}$ & $\begin{array}{l}\text { Male } 66 \% \\
\text { Female } 34 \%\end{array}$ & $\begin{array}{l}\text { Male } 68 \% \\
\text { Female } 32 \%\end{array}$ & $\begin{array}{l}\text { Male } 72 \% \\
\text { Female } 28 \%\end{array}$ \\
\hline $\begin{array}{l}\text { Follow up/ } \\
\text { months }\end{array}$ & $1-12 \mathrm{~m}$. & $12-30 \mathrm{~m}$. & $24-60 \mathrm{~m}$. & $11-12 \mathrm{~m}$. & $11-12 \mathrm{~m}$. & $12-38 \mathrm{~m}$. & 3-35 m. \\
\hline Range of Motion & $1.5^{\circ}-130^{\circ}$ & $3.9^{\circ}-136.3^{\circ}$ & $0^{\circ}-120^{\circ}$ & $1^{\circ}-130^{\circ}$ & $1^{\circ}-109^{\circ}$ & $1^{\circ}-127^{\circ}$ & $1^{\circ}-116^{\circ}$ \\
\hline $\begin{array}{l}\text { Mean Knee } \\
\text { Score }\end{array}$ & $\begin{array}{l}\text { Function. } \\
\text { Rasmussen } \\
\text { Score } 94.4 \% \\
\text { Anatomical } \\
\text { Score } 92.6 \%\end{array}$ & $\begin{array}{l}\text { OxfordScore } \\
82.3 \% \\
\text { HSS Score } \\
89.6 \%\end{array}$ & NO score & NO score & $\begin{array}{l}\text { Mean HSS } \\
\text { score } \\
83.3 \%\end{array}$ & $\begin{array}{l}\text { Mean } \\
\text { Lysholm 90\% }\end{array}$ & NO score \\
\hline Malalign-ment & $5 \%$ & $6.67 \%$ & 0 & $22 \%$ & $25.8 \%$ & $5.8 \%$ & $17 \%$ \\
\hline Loss of fixation & 0 & $20 \%$ & 0 & $8 \%$ & $14.5 \%$ & 0 & $3 \%$ \\
\hline $\begin{array}{l}\text { Delayed/ Non } \\
\text { union }\end{array}$ & 0 & $6.67 \%$ & $11 \%$ & 0 & 1.6 & 0 & $3 \%$ \\
\hline $\begin{array}{l}\text { Wound } \\
\text { complica-tions }\end{array}$ & $5 \%$ & $6.67 \%$ & $11 \%$ & $22 \%$ & $6.5 \%$ & $5.8 \%$ & $4 \%$ \\
\hline $\begin{array}{l}\text { Other } \\
\text { complica-tions }\end{array}$ & $\begin{array}{l}\text { Preop. C.S. } \\
5 \% \\
\text { Hardware } \\
\text { irritation 5\% }\end{array}$ & $\begin{array}{l}\text { Preop. C.S. } \\
20 \%\end{array}$ & $\begin{array}{l}\text { Hardware } \\
\text { irritation } 16.6 \%\end{array}$ & $\begin{array}{l}\text { Postop. proneal } \\
\text { n. palsy } 2.7 \% \\
\text { Postop. C.S. } \\
2.7 \% \\
\text { Hardware } \\
\text { irritation } 10.8 \% \\
\end{array}$ & No & No & $\begin{array}{l}\text { Postop. } \\
\text { proneal n. } \\
\text { palsy } 1.3 \% \\
\text { Hardware } \\
\text { irritation } 5 \%\end{array}$ \\
\hline
\end{tabular}

literatures studying this issue. Soft tissue complications are a major concern in the treatment of bicondylar tibial plateau fractures with plates. The surgical approach and number of incisions are reported to have an effect on the incidence of soft tissue complications following repair of tibial plateau fractures [18]. With LISS fixation, it is reported to range from 0 to $22 \%[19,20]$. As regards dual plating fixation of bicondylar tibial plateau fractures, papers reporting the results of dual plating through a single extensile incision had shown an incidence of deep wound infection of $23-88 \%[18,21]$. With the two-incision double plating technique, the incidence drops to $4.7-8.4 \%[22,23]$.

The most debated complication of our study and other studies regarding efficacy of single lateral locked plate in providing fracture stabilization of bicondylar tibial plateau fractures is failure of fixation of medial component of the fracture. Parameters of failure in our case was ( joint depression $2 \mathrm{~mm}$., MPTA $83^{\circ}$, PPTA $9^{\circ}$ and condylar widening $3 \mathrm{~mm}$.). By analysis of geometry of fracture of the failed case, we found that articular component of the medial column fracture had coronal fracture line and small posteromedial fragment. Analysis of failed cases in other studies revealed that geometry of fracture had one of the following or collection of them: Medial intraarticular fracture line, Small comminuted medial plateau fragment, Medial articular fracture having a coronal component with posteromedial fragment.

The significance of posteromedial fragments in bicondylar tibial plateau fractures was recently addressed in the literature although both incidence and subsequent displacement are usually underestimated. Barei et al. [2] and Higgins et al [24]. Reported that the incidence rate of posteromedial fragments in patients with bicondylar tibial plateau fractures was $28.8-59 \%$. The presentation of posteromedial fragments makes reduction and fixation of complex plateau fractures more difficult, especially when a single fixed angle plate is used.

Several factors could explain why lateral locked plating is less effective for fractures with coronal medial fracture lines. The direction of locked screws is fixed and is, for the most part, parallel rather than perpendicular to a coronal fracture line. This may explain why the fixation failure was not seen with medial articular fracture lines in the sagittal plane. Furthermore, although the posterior medial fracture fragments may be small, it may serve a critical role in preventing posterior subluxation of the medial femoral condyle. Even when locking screws engage the fragment, the quality of the fixation may be inadequate to resist the forces of displacement [25].

limitations of our study include the following:Lack of a comparative group, therefore, we cannot determine if another 
method of treatment would have led to different results. The limited number of patients in our study is a weakness regarding statistical power. Short duration of study: the one-year results may not be sufficient for drawing final conclusions regarding functional outcome after these challenging fractures. It is possible that, with time, many of these patients may have post traumatic knee arthritic changes. It is possible, even probable, that the prevalence of degenerative change may increase with time.

\section{Conclusion}

Single lateral locked plate can be an effective implant in providing fracture stabilization of bicondylar tibial plateau fractures. For optimal results, indication of surgical treatment of bicondylar tibial plateau fractures by single lateral locked plate is: Bicondylar tibial plateau fractures with no medial articular fracture line. Bicondylar tibial plateau fractures with large non comminuted medial plateau fragment. Bicondylar tibial plateau fractures with medial articular fracture not having a coronal component. We suggest a future prospective study to compare different types of fixation of bicondylar tibial plateau fractures, to know if there is any significant difference between them.

\section{Competing interests}

The authors declare that they have no competing interests.

\section{Authors' contributions}

\begin{tabular}{|l|c|c|c|c|c|}
\hline Authors' contributions & AHY & AN & WGA & SAO & HE \\
\hline Research concept and design & $\checkmark$ & $\checkmark$ & $\checkmark$ & -- & $\checkmark$ \\
\hline Collection and/or assembly of data & $\checkmark$ & $\checkmark$ & -- & -- & -- \\
\hline Data analysis and interpretation & $\checkmark$ & $\checkmark$ & $\checkmark$ & -- & -- \\
\hline Writing the article & $\checkmark$ & -- & -- & -- & -- \\
\hline Critical revision of the article & $\checkmark$ & -- & $\checkmark$ & $\checkmark$ & $\checkmark$ \\
\hline Final approval of article & -- & -- & $\checkmark$ & $\checkmark$ & $\checkmark$ \\
\hline Statistical analysis & $\checkmark$ & -- & -- & -- & -- \\
\hline
\end{tabular}

Publication history

Editor: Antonio G Tristano, Medical Center Carpetana, Spain. Received: 23-Apr-2017 Final Revised: 31-May-2017

Accepted: 05-Sep-2017 Published: 10-Sep-2017

\section{References}

1. 1.Schatzker J, Watson J.T, Levy B and Cole P. Tibial plateau fractures. In: Browner, Jupiter, Levine, Trafton, editors. Skeletal trauma. $4^{\text {th }}$ ed. Philadelphia, PA: WB Saunders Co. 2009; 2074-2131.

2. Barei DP, O'Mara TJ, Taitsman LA, Dunbar RP and Nork SE. Frequency and fracture morphology of the posteromedial fragment in bicondylar tibial plateau fracture patterns. J Orthop Trauma. 2008; 22:176-82. | Article | PubMed

3. Ehlinger M, Rahme M, Moor BK, Di Marco A, Brinkert D, Adam P and Bonnomet F. Reliability of locked plating in tibial plateau fractures with a medial component. Orthop Traumatol Surg Res. 2012; 98:173-9. I Article | PubMed

4. Ostrum RF and Geel C. Indirect reduction and internal fixation of supracondylar femur fractures without bone graft. J Orthop Trauma. 1995; 9:278-84. | PubMed
5. Bolhofner BR. Indirect reduction and composite fixation of extraarticular proximal tibial fractures. Clin Orthop Relat Res. 1995; 7583. | PubMed

6. Farouk O, Krettek C, Miclau T, Schandelmaier P, Guy P and Tscherne H. Minimally invasive plate osteosynthesis and vascularity: preliminary results of a cadaver injection study. Injury. 1997; 28 Suppl 1:A7-12. | PubMed

7. Rasmussen P.S. Tibial Condylar Fracture. J. Bone Joint Surg. [Am]. 1973; 55:1331-1350.

8. Freedman EL and Johnson EE. Radiographic analysis of tibial fracture malalignment following intramedullary nailing. Clin Orthop Relat Res. 1995; 25-33. | PubMed

9. Zura R.D, Browne J.A, Black M.D and Olson S.A. Current management of high energy tibial plateau fractures. Current Orthopaedics. 2007; 21:229-235.

10. Stannard JP, Wilson TC, Volgas DA and Alonso JE. The less invasive stabilization system in the treatment of complex fractures of the tibial plateau: short-term results. J Orthop Trauma. 2004; 18:552-8. | Article | PubMed

11. Cole PA, Zlowodzki M and Kregor PJ. Treatment of proximal tibia fractures using the less invasive stabilization system: surgical experience and early clinical results in $\mathbf{7 7}$ fractures. J Orthop Trauma. 2004; 18:528-35. | Article | PubMed

12. Gosling T, Schandelmaier P, Marti A, Hufner T, Partenheimer A and Krettek $C$. Less invasive stabilization of complex tibial plateau fractures: a biomechanical evaluation of a unilateral locked screw plate and double plating. J Orthop Trauma. 2004; 18:546-51. | Article | PubMed

13. Nikolaou VS, Tan HB, Haidukewych G, Kanakaris N and Giannoudis PV. Proximal tibial fractures: early experience using polyaxial locking-plate technology. Int Orthop. 2011; 35:1215-21. | Article | PubMed Abstract | PubMed FullText

14. Lee TC, Huang HT, Lin YC, Chen CH, Cheng YM and Chen JC. Bicondylar tibial plateau fracture treated by open reduction and fixation with unilateral locked plating. Kaohsiung J Med Sci. 2013; 29:568-77. | Article | PubMed

15. Spagnolo R and Pace F. Management of the Schatzker VI fractures with lateral locked screw plating. Musculoskelet Surg. 2012; 96:75-80. I Article | PubMed

16. Phisitkul P, McKinley TO, Nepola JV and Marsh JL. Complications of locking plate fixation in complex proximal tibia injuries. J Orthop Trauma. 2007; 21:83-91. | Article | PubMed

17. Gosling T, Schandelmaier P, Muller M, Hankemeier S, Wagner M and Krettek C. Single lateral locked screw plating of bicondylar tibial plateau fractures. Clin Orthop Relat Res. 2005; 439:207-14. | PubMed

18. Young MJ and Barrack RL. Complications of internal fixation of tibial plateau fractures. Orthop Rev. 1994; 23:149-54. | PubMed

19. Egol KA, Su E, Tejwani NC, Sims SH, Kummer FJ and Koval KJ. Treatment of complex tibial plateau fractures using the less invasive stabilization system plate: clinical experience and a laboratory comparison with double plating. J Trauma. 2004; 57:340-6. | Article | PubMed

20. Phisitkul P, McKinley TO, Nepola JV and Marsh JL. Complications of locking plate fixation in complex proximal tibia injuries. J Orthop Trauma. 2007; 21:83-91. | Article | PubMed

21. Moore TM, Patzakis MJ and Harvey JP. Tibial plateau fractures: definition, demographics, treatment rationale, and long-term results of closed traction management or operative reduction. J Orthop Trauma. 1987; 1:97-119. | PubMed

22. Barei DP, Nork SE, Mills WJ, Henley MB and Benirschke SK. Complications associated with internal fixation of high-energy bicondylar tibial plateau fractures utilizing a two-incision technique. J Orthop Trauma. 2004; 18:649-57. | Article | PubMed 
Youssef et al. Journal of Rheumatology and Orthopedics 2017,

23. Stevens DG, Beharry R, McKee MD, Waddell JP and Schemitsch EH. The long-term functional outcome of operatively treated tibial plateau fractures. J Orthop Trauma. 2001; 15:312-20. | Article | PubMed

24. Higgins TF, Kemper D and Klatt J. Incidence and morphology of the posteromedial fragment in bicondylar tibial plateau fractures. J Orthop Trauma. 2009; 23:45-51. | Article | PubMed

25. Weaver MJ, Harris MB, Strom AC, Smith RM, Lhowe D, Zurakowski D and Vrahas MS. Fracture pattern and fixation type related to loss of reduction in bicondylar tibial plateau fractures. Injury. 2012; 43:864-9. | Article I PubMed

\section{Citation:}

Youssef AHE, Nagi A, Senna WGA, Othman SA and Elgamal $\mathrm{H}$. Does single locked plating provide a standard treatment Modality for bicondylar tibial plateau fractures? A prospective study. J Rheumatol Orthop. 2017; $4: 2$.

http://dx.doi.org/10.7243/2055-7000-4-2 